\title{
HUMAN IMPACTS ON SUB-ANTARCTIC TERRESTRIAL ENVIRONMENTS
}

\author{
by D. M. Bergstrom and P. M. Selkirk
}

(with one plate and three tables)

\begin{abstract}
Bergstrom D.M. \& Selkirk, P.M. 2007 (23:xi): Human impacts on sub-Antarctic terrestrial environments. Papers and Proceedings of the Roya!SocietyofTasmania 141(1):159-168. https://doi.org/10.26749/rstpp.141.1.159 ISSN 0080-4703. Australian Antarctic Division, Department ofEnvironment and Water Resources, 203 Channel Highway, Kingston, Tasmania 7150, Australia $\left(\mathrm{DMB}^{\star}\right)$; Department of Biological Sciences, Macquarie University, Sydney, NSW 2109, Australia (PMS). *Author for correspondence.
\end{abstract}

Sub-Antarctic islands are some of the rarest ecosystems on the planet and therefore are highly significant. Around 200 years of human activities have left a legacy of substantial impacts. We explore these under the collective headings of resource harvesting, local impacts and habitat loss, homogenisation of biota and human-influenced climate change. Past human activities such as sealing and whaling have left seal species still in recovery phases, and infrastructure that continues to break down and pollute the local environment. Modern-day scientific stations have variously-sized footprints of buildings and tracks, and legacies of contaminants, particularly oils spills. On some islands, alien species have established and there is a range of impacts associated with such taxa ranging from transient to extensive, permanent transformation of ecosystems. Such impacts are being confounded by human-induced climate change. By projection, it is expected that both direct and indirect human impact will continue into the future. It is appropriate to plan all future human activity in ways that will minimise further burden on these ecosystems.

Key Words: sub-Antarctic islands, human impacts, homogenisation of biota, climate change, alien species, contaminants.

\section{INTRODUCTION}

When considering the range of human impacts on Antarctica, Hull \& Bergstrom (2006) discussed four categories: (1) resource extraction and harvesting; (2) local impacts and habitat loss; (3) homogenisation of biota; and (4) humaninfluenced climate change. Extending their examination northward, we use these four categories to examine human impacts in the sub-Antarcticregion. Our focus is principally on terrestrial and limnetic ecosystems, and does not significantly consider birds and seals which spend most of their time in the marine environment.

\section{RESOURCE EXTRACTION AND HARVESTING}

\section{Geological resource extraction}

To our knowledge, no substantial mining, i.e., extraction of geological resources, for export has occurred or is currently occurring on any sub-Antarctic island. Local small-scale mining for on-island building activities that would be deemed to have "local impact" has occurred at many islands. In addition, at many of the medium-to-large stations, sediments and aggregates for building (such as building sand and aggregate for concrete) have been and are imported for building purposes. Mostsub-Antarctic islands are governed by management plans which offer protection of geological as well as biological and cultural values (Whinam et al. 2006).

\section{Biological resource harvesting}

Biological resources were extensively extracted from subAntarctic islands from the late eighteenth to the early twentieth century, harvesting first fur seals, then elephant seals and later penguins. On Macquarie Island the slaughter of fur seals from populations that had existed on the island for at least 8000 years (Bergstrom 1987) led to their local extinction on the island in less than a decade (Shaughnessy et al. 1988). We still do not know what species of fur seal was present during sealing times.

On South Georgia, the Antarctic Fur Seal (Arctocephalus gazella (Peters, 1875)) was harvested almost to extinction with over a million seals killed by the early 1800s (Weddell 1825 in Boyd 1993). Elephant Seals (Mirounga leonina (Linnaeus, 1758)) were also taken during the nineteenth century but had recovered sufficiently by 1909 to allow for a second phase of sealing. From 1952 the industry was carefully regulated and managed sustainably based on scientific information and principles. A detailed quota system of around 6000 adult bulls per year was enforced until cessation of sealing, along with whaling, in 1964-65 (Headland 1984, McIntosh \& Walton 2000).

Since sealing ceased, there has been some population recovery on all islands (Boyd et al. 1990, Page et al. 2003, Hucke-Gaete et al. 2004) with a total population growth rate of around $20 \%$ per year on most islands at some stage during recovery. On some islands, population recovery is through recolonisation from other islands rather than local breeding. Genetic analyses indicate that Îles Crozet and Macquarie Island have been recently recolonised by female Sub-Antarctic Fur Seals (Arctocephalus tropicalis (J.E. Gray, 1872)) from Marion Island and to a smaller extent, from Île Amsterdam, while South Georgia and Bouvetoya were probable sources for populations of Antarctic Fur Seals at Marion and Heard islands (Wynen et al. 2000). Recovery of fur seals on Macquarie Island, however, has been slow and complex due to recolonisation by three species ( $A$. gazella, A tropicalis and $A$. forsteri (Lesson, 1828) - New Zealand Fur Seal) and hybridisation between them (Lancaster et al. 2006). Rates of hybridisation are now falling, however, due to greater influxes of pure Antarctic and Sub-Antarctic Fur seals and non-random mating.

Biological harvesting impacted coastal and inland terrestrial ecosystems both directly and indirectly. First, the harvesting of seals and penguin from colonies in near-shore 
environments would have removed a disturbance factor and provided open habitat for recolonisation by coastal plants. However, harvesting would also have reduced the supply of marine nutrients that penguin and seals deposit on shore as waste. These are subsequently blown inland either as particulate matter or volatilised ammonia (Erskine et al. 1998).

Seal colonies progressively recovered, for example on South Georgia from a few tens of individuals at the beginning of the 1900 s to over 900000 by the mid-1980s (Bonner 1985), and from local extinction on Heard Island to around 30000 in 1993 and 2001 (Page et al. 2003). As populations increased, the disturbance factor to the terrestrial environment has been reinstalled. The increase of Antarctic Fur Seals on South Georgia has had a profound impact on local vegetation with destruction from trampling of the dominant tussock grass, Parodiochloa flabellata (Lam.) C.E.Hubb., Deschampsia antarctica E.Desv. and cryptogamic meadows. Destruction of the tussock has reduced petrel breeding habitat and general loss of vegetation has increased erosion rates (Bonner 1985). Similarly on Heard Island, we have observed numerous plants of Pringlea antiscorbutica R.Br. ex Hook.f., calculated to be over 40 years old (D.M. Bergstrom \& K. Keifer unpublished data), being destroyed by fur seals as they moved between land and shore. On coastal slopes on Heard Island Pringlea occurs in extensive monospecific stands which may be artefacts resulting from release from seal disturbance, and their current destruction may reflect a return to pre-sealing conditions.

\section{LOCAL IMPACTS AND HABITAT LOSS}

\section{Footprint of past activities}

Many impacts can be categorised as "local impact and habitat loss". Past sealing and/or whaling industrial activities occurred on most of the major islands in the sub-Antarctic. All activities have left some form of legacy in terms of the footprints of occupation, now termed "historic sites". The most prominent cluster in the region is the seven abandoned whaling stations and shore based-facilities on the northeast coast of South Georgia (pl. 1A). Of these, Husvik, Grytviken, Stromness and Leith Harbour were abandoned intact in 1965. Since then there has been limited clean-up (McIntosh \& Walton 2000), leaving effectively abandoned industrial sites, complete with asbestos problems in some localities. In 2003 clean-up activities began at Grytviken, including removal of wind-blown building debris, burial of asbestos and the removal of oils from shore tanks and partly submerged whale catchers. Similar work is still needed at other whaling stations but is restricted by lack of funds (Pasteur \& Walton 2006). Similarly, the abandoned whaling/sealing station at Port Jeanne d'Arc on Grande Terre of Îles Kerguelen has left a large footprint of old huts and equipment, now partially restored and periodically visited by tourists (pl. 1B).

Other sub-Antarctic sealing and whaling industrial sites have left artefacts such as the remains of huts, cave usage, try pots, work platforms, boilers and digesters and other harvesting paraphernalia. It terms of loss of habitat, many historic sites have been partially reclaimed, overgrown by vegetation (Whinam et al. 2004), covered by wind-blown sand and occupied by animals (see pl. 1C). Shipwrecked sailors also left artefacts and evidence of occupation.

\section{Footprint of present activities}

Current human activities on sub-Antarctic islands fall into three categories: commercial fisheries, national programs and tourism activities (both through an established industry and private expeditions).

The fishing activity that occurs around most islands has a number of terrestrial impacts. First, marine debris washing up on sub-Antarctic shores (Slip \& Burton 1991, Convey et al. 2002) included fishing nets, floats and associated plastics such as packaging bands. Between $40 \%$ on Heard Island and $30 \%$ on Macquarie Island of all marine debris has been interpreted as fishing derived; the balance reflects the global issue of human rubbish circulating in the world's oceans (Slip \& Burton 1991). A second impact comes from fisheries by-catch reducing the number of seabirds, notably albatrosses and petrels, that would otherwise breed on the islands, a problem that is being addressed by changes in fishing techniques (Gales 1998, Croxall 1998, McIntosh \& Walton 2000). A third potential impact from fisheries is through landings by ships' crews, but this currently has not been investigated.

Impacts from national programs are mainly associated with stations and the hub and spoke footprint that emanates from them including tracks, field camps and field huts. The size of this impact varies with the size of the human population and extent of infrastructure. The largest station, Port aux Français on Îles Kerguelen (pl. 1D), with a population of between 50 and 100 people, has multiple facilities including roads, street lighting, radar fields and a space station. McDonald Island has no human presence or any evidence of human impact, and has not been officially visited since the early 1980s. Table 1 summarises the degree of human infrastructure on the larger islands in the region (see also pl. $1 \mathrm{E}-\mathrm{H})$. In general, the size of the footprint of habitat loss by human infrastructure is small compared to the overall size of the islands, but most bases are positioned on the coast and these are usually areas with high population densities of seabirds and seals. For example, the wharf and road to the station at 1̂le de la Possesssion is through a King Penguin (Aptenodytes patagonicus Miller, 1788) colony (pl. 1G) and nearby are Wandering Albatross (Diomedea exulans Linnaeus, 1758) nesting areas. The station at Macquarie Island is only metres away from Elephant Seal and Rockhopper Penguin (Eudyptes chrysocome Hutton, 1879) colonies. Despite the inevitable disturbance that humans bring, these animals still congregate and breed successfully at these sites.

In the sub-Antarctic, the creation and persistence of tracks are dependent on the rate of foot traffic along the tracks and on local environmental conditions, as in cool temperate alpine areas (Whinam \& Chilcott 1999). On Macquarie Island trench erosion to rock rubble has occurred in a highuse area of track through feldmark vegetation; and in an area of high traffic through coastal slope vegetation (Poa foliosa (Hook.f.) Hook.f. and Stilbocarpa polaris (Hombr. \& Jacquinot ex Hook.f.) A.Gray on deep peat, the track became eroded to deep muddy trenches and holes (Scott \& Kirkpatrick 1994). Active management of such severely eroded sites is essential for long-term impact minimisation (as is now the case at these sites: boardwalk at the feldmark site, traffic control at the coastal slope site, Dixon 2001). Tracks are also pathways for alien species invasion from the station hub to elsewhere (Frenot et al. in press).

Regular sub-Antarctic tourism is associated mainly with two islands, South Georgia and Macquarie Island. Minor 

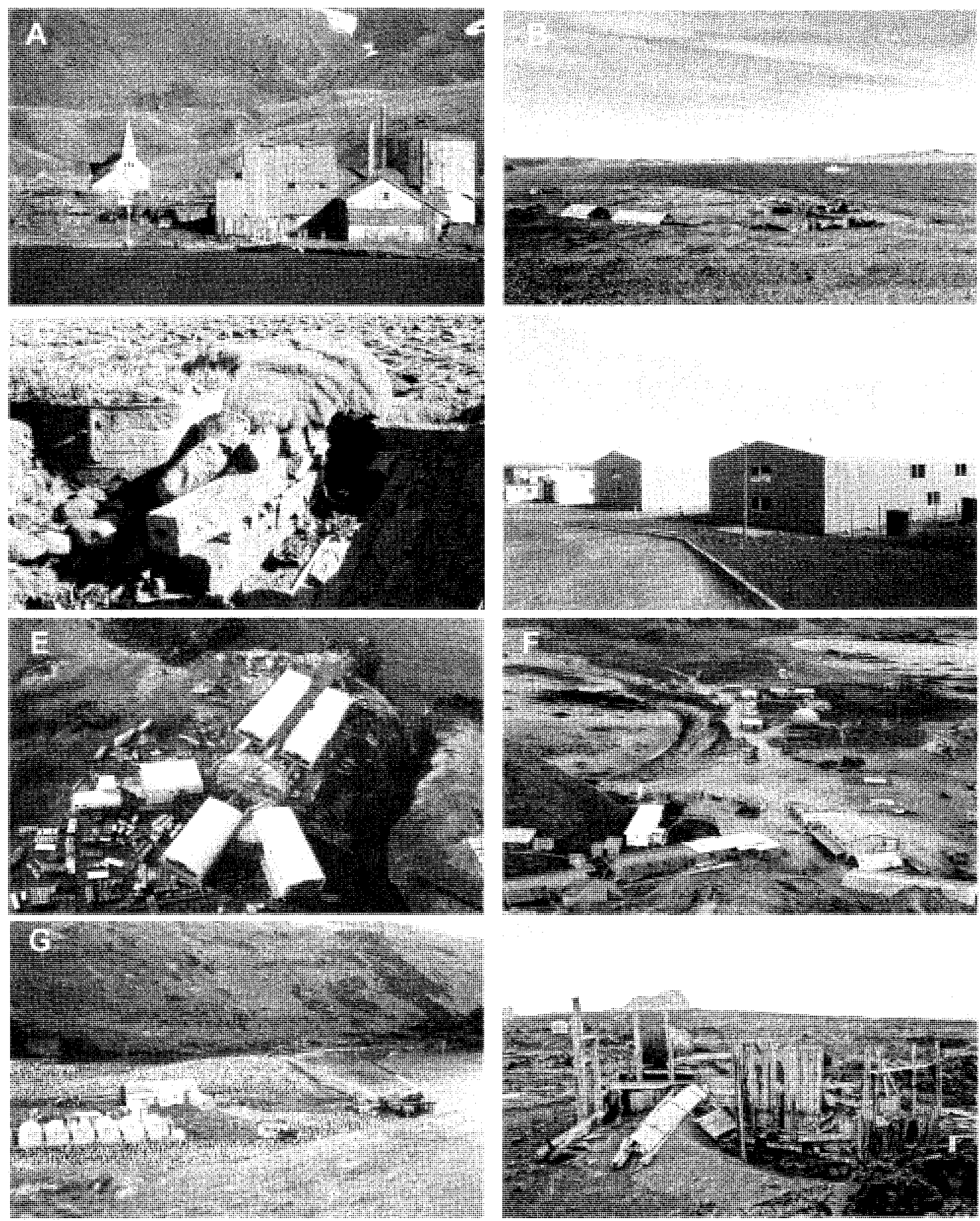

PLATE I

(A) Abandoned whaling station at Grytviken, South Georgia, 2007. Note modern tourist yacht in foreground (photographer: $M$. Davidson). (B) Abandoned whaling station at Port Jeanne d'Arc, Illes Kerguelen, 2002 (photographer: K. Kiefer). (C) Abandoned trypot covered in vegetation, Spit Bay, Heard Island, 2004 (photographer: K. Kiefer). (D) Buildings at Port aux Francais, Iles Kerguelen, 2003 (photographer: J. Deere). (E) New base under construction with associated construction material and containers, Marion Island, April 2006 (photographer: S.L. Chown). (F) Macquarie Island Station, 2007 (photographer: K. Kiefer). (G) Landing beach and infrastructure, Ile de la Possession, 2003 (photographer: D.M. Bergstrom). (H) Abandoned station with semi-permanent huts in distance at Atlas Cove, Heard Island, 2003 (photographer: K. Kiefer). 
TABLE 1

Summary of current footprint of stations on major sub-Antarctic islands

\begin{tabular}{|c|c|c|c|c|c|c|c|c|c|}
\hline & 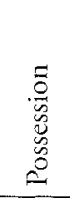 & $\begin{array}{c}\overrightarrow{w_{3}} \\
\text { 壵 }\end{array}$ & 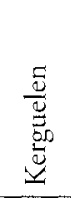 & $\begin{array}{l}\overrightarrow{\mathrm{J}} \\
\stackrel{\text { I }}{\underline{I}}\end{array}$ & 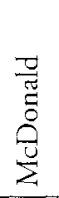 & 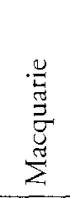 & 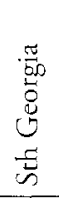 & 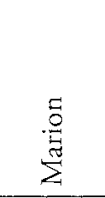 & 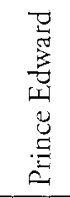 \\
\hline Visitation & A & $\mathrm{R}$ & A & $\mathrm{R}$ & $\mathrm{N}$ & A & A & $A$ & $\mathrm{R}$ \\
\hline Permanent station & + & - & + & - & - & + & - & + & - \\
\hline Permanent roads & + & - & + & - & - & + & + & - & - \\
\hline Maximum human & $<50$ & 0 & 100 & $<30^{2}$ & 0 & $<50$ & 30 & $<100^{3}$ & $<20^{2}$ \\
\hline Fuel Farm & + & - & + & - & - & + & - & + & - \\
\hline Historic sites & + & - & + & + & - & + & + & + & + \\
\hline Field huts & + & - & + & + & - & + & + & + & - \\
\hline Walking tracks & + & - & + & - & - & + & + & + & - \\
\hline Agriculture & - & - & + & - & - & - & - & - & - \\
\hline Glasshouse/ hydroponics & + & - & + & - & - & + & - & - & - \\
\hline Additional infrastructure & - & - & + & - & - & - & - & - & - \\
\hline
\end{tabular}

A annual, $\mathrm{R}$ rare, $\mathrm{N}$ none, ${ }^{1}$ excluding tourist numbers, ${ }^{2}$ periodic visitation, ${ }^{3}$ inflated due to rebuilding program. + yes/present, - no/absent.

tourism (fewer than 10 people per voyage) does occur with the French national program to Îles Crozet and Îles Kerguelen. Occasionally tourist ships visit Heard Island and fishing control vessels sometimes have brief landings for management and recreational purposes. On Macquarie Island activities are restricted to controlled commercial educational tourism with a limit on total numbers of around 750 tourists per year (Parks and Wildlife Service 2006). Activities are limited to landing at two localities (the Australian Station at Buckles Bay and Sandy Bay) and cruising in Zodiac boats offshore from a large King Penguin colony. Some infrastructure (duck-board and viewing platforms) is in place at the two landing localities. One such structure has recently been undermined by a landslip, in an area grazed by European Rabbits (Oryctolagus cuniculus (Linnaeus, 1758)).

South Georgia has the greatest level of tourism in the subAntarctic. Most activities are based around the old whaling stations, the British Antarctic Survey base and areas of scenic beauty and wildlife congregation. The island has the largest number of tourist landings (upward of 4000 per summer season) due to its proximity to South America and has a large number of other vessels such as fishing vessels visiting as well (Frenot et al. 2005) (see pl. 1A). Tourist activities range from exploring historic sites and coastal areas, to ice climbing and retracing Shackleton's epic west-east trek across the spine of the island.

Whereas tourism is very controlled on Macquarie Island with ranger supervision, many tourist activities on South Georgia are unsupervised. For larger or remote islands there is little information available on uncontrolled short-term visits by small vessels such as yachts. Sequential island-hopping by vessels poses a potential threat to island ecosystems through poor quarantine standards and non-compliance with permit conditions. Tourist ships often schedule visits to the Falkland Islands before they visit South Georgia. The practice of visiting warmer islands before colder ones provides pathways for potentially transferring propagules of both native and alien species southwards.

\section{Contamination}

Contamination on sub-Antarctic islands follows a similar pattern to those summarised in Hull \& Bergstrom (2006) for the Antarctic. All lands are subjected to some degree of long-range airborne contaminants from remote sources such as PCBs; however, as sub-Antarctic islands are distant from inhabited continents, they will be, like Antarctica, at the lower end of the global contamination scale. Such contaminants are known generally to accumulate in top-order predators.

Waste and contaminants associated with local occupation both in the past (legacy wastes) and present are the main group of contaminants in the sub-Antarctic. Wastes and contaminants from onshore sealing and whaling activities during the "historical era" would have been substantial. On South Georgia summer populations of up to 2000 men processed thousands of whale carcases. There was domestic waste and sewage associated with the human population, as well as industrial waste and contaminants discharged onto land and into ocean and atmosphere. Residues have been found in inshore marine sediments and benthic invertebrates. Whale bones are still visible, scattered on land in the vicinity of former whaling stations (Headland 1984). Waste whale carcase debris probably supported larger populations of scavenging birds than at present.

Contaminants from the "modern era", the past 50 years, are better-documented. Oil spills, rubbish dumps and sewage effluent are the main point sources. Other point sources include emissions from the operation of incinerators at stations and huts; non-point source emissions include aerially dispersed contaminants from vehicles (Deprez et al. 1994 , Poland et al. 2003, Hull \& Bergstrom 2006).

Past and present oils spills have occurred on most sub- 
Antarctic islands. Large oil spills have occurred either near or within station limits on both Macquarie Island and Île de la Possession. The spill at Île de la Possession in 1997 occurred from an underground pipe at the Alfred Faure station. An estimated $20000 \mathrm{~L}$ of diesel fuel drained through the ground to re-emerge some $200 \mathrm{~m}$ down slope in an area containing both arid fellfield vegetation and an area of wet closed vegetation. The area affected was approximately 1200 $\mathrm{m}^{2}$. After one year $45 \%$ of hydrocarbons had been degraded by indigenous bacteria in some areas. However Coulon \& Delille (2006) noted that the success of bioremediation depended on the characteristics of both the contaminant and substrate.

On Macquarie Island a number of fuel spill contaminated sites are associated with the station, particularly around the fuel farm, powerhouses and diesel mechanics' workshop (Deprez et al. 1994). Rayner et al. (2007) investigated potential means to bioremediate three petroleum-hydrocarbon spills associated with the fuel farm and powerhouses. They noted that bioremediation of subpolar soils can be limited by low nutrients, low temperatures and excess water causing anaerobic conditions. Their experiments reported on the success of a "microbioventing" system, comprising many small air-injecting rods that successfully aerated a wide area of soil and increased natural biodegradation rates of indigenous bacteria.

\section{Agriculture}

Agricultural practices were commonplace in the early human histories of most sub-Antarctic islands. Sheep (Ovis aries Linnaeus, 1758) were introduced to most sub-Antarctic islands with early sealing or scientific expeditions together with hay for feed which inadvertently introduced a number of agricultural alien plant species. A population of around 3000 sheep can still be found on Île Longue (Îles Kergeulen) (Chapuis et al. 1994) and are a major protein food source for expeditioners. Sheep are rounded up by a shepherd and sheep dog during summer months and transported live by barge to the abattoir at Port aux Français. Bourzat \& Monie (1977 in Frenot et al. in press) reported "pasture improvement" practices were tried on Île Longue and another small island with seeding of European pasture grasses (Elymus repens (L.) Gould, Dactylis glomerata Linnaeus, Festuca ovina Linnaeus, F arundinacea Schreber, Lolium perenne Linnaeus, Poa pratensis Linnaeus and Pbleum pratense Linnaeus) in the 1970s. These species have established successfully and outcompeted native species. An examination of sheep paddocks near sheep infrastructure in early 2004 yielded only three indigenous species from a total expected native biodiversity of up to 25 plant species (N.J.M. Gremmen pers. comm.). This represents a substantial loss of native biodiversity. Mouflon (Ovis musimon Pallas, 1762) are present on Île Haute and reindeer (Rangifer tarandus Linnaeus, 1758) on Grande Terre of Îles Kerguelen (Chapuis et al. 1994).

On South Georgia, sheep were also confined to a single island, Mutton Island, off Husvik, but none remain. Following three introductions from Norway, two distinct populations of reindeer are still present on South Georgia (Leader-Williams 1988, Anon 2005), the Busen and Royal Bay herds, formerly confined to relatively small areas by adjacent glaciers. As glaciers have retreated with recent climate change, the reindeer have gained access to a larger area (Lindsay 1973), and they now occupy the most extensive and species-rich vegetated areas on South Georgia. Their grazing has caused degradation of vegetated areas and erosion of bare areas (McIntosh \& Walton 2000). The continuing glacial retreat provides potential access for reindeer into new areas, leading to probable further degradation of plant communities (Moen \& MacAlister 1994). Partly to satisfy the intense scientific interest in the genetics of these isolated populations, and partly to facilitate establishment of a commercial reindeer herd in the Falklands, in 2001 and 2002 fawns were translocated from the South Georgia herds to the Falkland Islands where they have been successfully established (Pasteur \& Walton 2006). To minimise further environmental damage, eradication of the Busen herd within five years is planned, with eradication of the Royal Bay herd to be considered subsequently (Pasteur \& Walton 2006).

\section{HOMOGENISATION OF BIOTA}

The most serious impact of humans on sub-Antarctic islands concerns the global issue of homogenisation of biota and the impact resulting from alien species. This topic has recently been reviewed substantially in Frenot etal. (2005, in press) and Convey et al. (2006). The main messages from these studies is that alien species richness, to a large extent, correlates with island size, visitation rates by people and temperature, with colder islands less susceptible to invasion than warmer ones (Chown et al. 1998, 2005).

A total of 108 alien vascular plant species has been recorded from the sub-Antarctic (table 2). Île Pingouins (Îles Crozet) and McDonald Island are free of alien plants and Îles Kerguelen has the dubious distinction of having the highest record with 69 alien species. Most species are classified as "persistent" and may have little detrimental impact beyond their presence; however, some notable species are "invasive" resulting in loss of local biodiversity (Frenot et al. 2005, in press). Grasses and daisies are the most common type of alien species with the winter grass (Poa annua Linnaeus) being the most widespread in the region. Other notable species (most European in origin) include Cerastium fontanum Baumgarten, Rumex acetosella Linnaeus, Stellaria media (L.) Villars, Sagina procumbens (Linnaeus) and Poa pratensis.

Seventy-one taxa of alien invertebrates have been recorded across the sub-Antarctic region (table 2). The most common groups are flies, aphids, beetles, mites and Collembola (springtails). Alien vertebrates include fish, rodents, rabbits, cats (Felis catus Linnaeus, 1758), birds and as mentioned above sheep, mouflon and reindeer (tables 2 and 3).

TABLE 2

Total number of alien species recorded from sub-Antarctic islands

\begin{tabular}{|c|c|c|c|c|c|c|c|}
\hline & 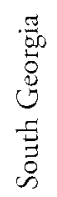 & 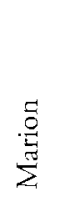 & 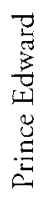 & 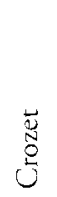 & 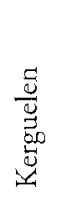 & 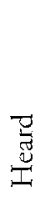 & 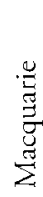 \\
\hline Vascular plants & 33 & 13 & 3 & 59 & 69 & 1 & 3 \\
\hline Invertebrates & 12 & 18 & 1 & 14 & 30 & 3 & 28 \\
\hline Vertebrates & 3 & 1 & 0 & 4 & 12 & 0 & 6 \\
\hline
\end{tabular}

From Frenot et al. (2005). 
TABLE 3

Number and types of alien vertebrates established on sub-Antarctic islands

\begin{tabular}{|c|c|c|c|c|c|c|c|c|c|}
\hline & & & & \multicolumn{3}{|c|}{ Crozet } & \multirow[b]{2}{*}{ 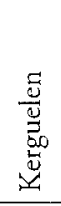 } & \multirow[b]{2}{*}{ 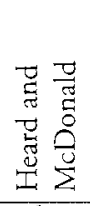 } & \multirow[b]{2}{*}{ 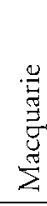 } \\
\hline & 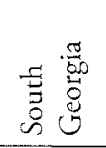 & $\stackrel{5}{\stackrel{0}{\frac{0}{\pi}}}$ & 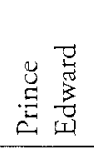 & 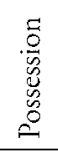 & $\ddot{4}$ & $\begin{array}{c}\tilde{0} \\
\tilde{0} \\
0 \\
0 \\
0\end{array}$ & & & \\
\hline Ships rat & & & & + & & & + & & + \\
\hline Black rat & + & & & & & & & & \\
\hline Mice & + & + & & & & + & + & & + \\
\hline Rabbits & & & & & + & + & + & & + \\
\hline Sheep & & & & & & & + & & \\
\hline Mouflon & & & & & & & + & & \\
\hline Reindeer & + & & & & & & + & & \\
\hline Cat & & $x$ & & & & + & + & & $x$ \\
\hline Trout & & $x$ & & +1 & & & $t^{2}$ & & \\
\hline Salmonid fish & & & & & & & + & & \\
\hline Mallard & & & & & & & & & + \\
\hline Starlings & & & & & & & & & + \\
\hline Red polls & & & & & & & & & + \\
\hline Weka & & & & & & & & & $x$ \\
\hline $\begin{array}{l}\text { Total alien } \\
\text { vertebrate species }\end{array}$ & 3 & 1 & 0 & 3 & 1 & 3 & 12 & 0 & 6 \\
\hline
\end{tabular}

+ species present, $X$ species has died out or has been removed through eradication activities.

1 Two species.

${ }^{2}$ Four species.

From Frenot et al. (2005).

The majority of alien invertebrates, plants and rodents were accidental introductions, but some alien species were purposely introduced for other reasons such as pasture improvement (as described above), as food in the case of rabbits, fish and the ungulates or as transport (horses on Macquarie Island and South Georgia; Headland 1984, Cumpston 1968, K. Kerry pers. comm.). The European rabbit flea was purposely introduced to Macquarie Island to carry the introduced Myxoma Virus to assist with rabbit control (Copson \& Whinam 2001).

Some alien species have died out naturally such as trout on Marion Island (Cooper et al. 1992) and some transient alien plant species (Frenot et al. 2005). Some alien species have been actively removed through eradication processes, such as removal of founder populations of Anthoxanthum odoratum Linnaeus and Rumex crispus Linnaeus on Macquarie Island (Copson \& Whinam 2001) and eradication of cats from Macquarie and Marion islands (Bester et al. 2000, Copson \& Whinam 2001, Parks and Wildlife Service 2006).

Impacts of alien species include both ditect and indirect impacts, including substantial loss of local biodiversity, changes to ecosystem processes and changes to ecosystem evolution. Some species are reaching "transformer status" (sensu Richardson et al. 2000). On Marion Island, two invasive plants species, Sagina procumbens and Agrostis stolonifera Linnaeus, are expanding their distributions and dominating various habitats, modifying both vegetation and associated fauna (Gremmen et al. 1998, Gremmen \& Smith 1999).
Rabbits can be considered as a transformer species on both Grande Terre in Îles Kerguelen and Macquarie Island, as can reindeer on South Georgia where they have significantly altered ecosystems through grazing (Copson \& Whinam 1998, Moen \& MacAlister 1994, McIntosh \& Walton 2000). Rabbits also possibly contributed to the extinction of the Macquarie Island parakeet and land rail which had co-existed with cats for 70 years before rabbit arrival (Taylor 1979). On Grand Terre large areas are dominated by Poa annua (alien) and Acaena magellanica (Lam.) Vahl (native) with other species having been selectively grazed. Acaena magellanica expands vegetatively in these areas, as even their inflorescences are grazed. On Macquarie Island, rabbits were controlled for a substantial period through an integrated pest management regime (Copson \& Whinam 2001). Their numbers appear to have increased recently and a range of compounding factors have been suggested as the cause: the removal of feral cats, built-up resistance to Myxoma Virus used to reduce rabbit numbers annually, the stopping of use of Myxoma due to its unavailability, climate change resulting in increased rabbit winter survival. Coastal slope vegetation in particular is being removed through grazing, possibly contributing to soil erosion and landslips (Parks and Wildlife Service 2006, Springer 2006). Bergstrom et al. (2006) reported that rabbits may also be impacting on ecosystem evolution on the island through restricting the expansion of a recently colonised grass species, Poa litorosa Cheesman. 
Sub-Antarctic island ecosystems have evolved in isolation and such ecosystems lack resilience to alien species invasions. Many ecosystems have missing functional groups that can be easily filled by alien species (Bergstrom \& Chown 1999). This has occurred on both South Georgia and Îles Kerguelen where carnivorous beetles have been introduced (see Convey et al. 2006 for full discussion) and these species are preying on native populations of invertebrates that became established within sub-Antarctic ecosystems without predator pressure.

\section{HUMAN-INFLUENCED CLIMATE CHANGE}

The final human impact to discuss here is that of current human-mediated climate change. Convey (2006) describes climate change in terms of impacting on four key parameters: temperature, free water availability, UV-B radiation and carbon dioxide levels. Changes in temperature and water availability have been noted on some islands; UV-B and $\mathrm{CO}_{2}$ levels have not been extensively studied in the subAntarctic. Increases in temperatures have been recorded from many sub-Antarctic islands (Adamson et al. 1988, Smith \& Steenkamp 1990, Frenot et al. 1997, Tweedie \& Bergstrom 2000, Smith 2002, Le Roux \& McGeoch, in press). There have been decreases in precipitation at both Marion Island and Îles Kerguelen since the early 1950s (Smith \& Steenkamp 1990, Frenot et al.1997, Smith 2002, Chapuis et al. 2004, Le Roux \& McGeoch in press).

Impacts of these changes include changes in local vegetation types (Smith et al. 2001) and animal-plant interactions (Chown \& Smith 1993). On Macquarie Island the distribution of Sphagnum appeared to be expanding through the 1980 s. The reduction in area of patches between 1992 and 2004 is interpreted as due to a period of desiccation in 1999-2000 (Whinam \& Copson 2006). On all subAntarctic islands with extant ice caps, warming has resulted in glacial retreat and greater land exposure (see Frenot $e t$ al. 1997, Gordon \& Timmis 1992, Sumner et al. 2004, Ruddell 2006). Recolonisation of these glacial forelands by both indigenous and alien species has been documented in detail (Scott 1990, Frenot et al. 1997, Frenot et al. 1998, Scott \& Bergstrom 2006). There is also some evidence of Acaena magellanica overgrowing Azorella selago Hook.f. at lower altitudes (Scott \& Bergstrom 2006).

On Heard Island the distribution of Poa annua is expanding at an alarming rate (Scott \& Kirkpatrick 2005). Whether this is related to climate warming is as yet unclear. Expansion of alien species and increased opportunity for alien species establishment or phase change (from persistent to invasive, from invasive to transformer species) is predicted to be one of the major changes on sub-Antarctic islands associated with climate change (Selkirk 1992, Convey et al. 2006).

\section{CONCLUSIONS AND PATHS FORWARD}

There are only a few sub-Antarctic island groups on the planet: six to eight, depending on how one classifies their ecosystems. This means that sub-Antarctic islands are some of the rarest ecosystems on the planet, making them very significant. Some have been more heavily impacted by human activities than others. Those which have been least impacted, McDonald Island, Prince Edward Island, some of the outer islands of
Îles Kerguelen and Heard Island, are of particular significance and require greater vigilance in their management.

The impact of past human activities such as sealing and whaling continues to the present, with species recovery still occurring and the infrastructure from such activities breaking down and polluting their local environments. Some scientific infrastructure, such as the abandoned Atlas Cove station at Heard Island, is still polluting the local environment despite many attempts at clean-up. The constant harsh sub-Antarctic environment applies significant stressors to human structures and any placement of new infrastructure must be accompanied by a plan for its removal before it is destroyed by the environment.

By far the greatest threat to sub-Antarctic ecosystems is the impact of alien species and the confounding effect of climate change to conditions which may favour non-native species. Some alien species have been eradicated, such as cats on Marion and Macquarie islands. Vertebrates by and large can be removed if sufficient resources are made available as long as an integrated pest management system is put in place. Most sub-Antarctic islands have persistent alien plant species. Removal of alien plants at this stage is desirable but to eradicate extensive populations of invasive plant species and any alien invertebrates is very difficult if not impossible. Such invasions inevitably cause permanent change to the ecosystem.

Chown et al. (2005) reported that alien plant and insect species on Southern Ocean islands (including the subAntarctic islands) covaried with human visitation rates. Whinam et al. (2005) began the study of examining pathways of alien propagules into the sub-Antarctic, identifying cargo, food and expeditioners' clothing, gear and equipment as all potential means of transport to these remote islands. They also demonstrated the success of adaptive management practices to prevent propagule transport. Australia and South Africa now have strong quarantine management practices in place. Whinam et al. (2005) also highlighted the difficulty in applying such quarantine practices to tourism operations. In particular the large size and unregulated nature of tourist operations make South Georgia stand out as now under serious threat.

Clearly humans and their activities have impacted substantially on sub-Antarctic terrestrial ecosystems in the past and in continue to do so in the present. By projection it must be expected that both direct and indirect human impact will continue into the future. The overwhelming message is that there is need for prevention as well as cure. It is appropriate to plan all future human activity in the rare sub-Antarctic ecosystems in ways that will minimise further impact.

\section{REFERENCES}

Adamson, D.A., Whetton, P. \& Selkirk, P.M. 1988: Warming on Macquarie Island: temperature changes reflecting Southern Hemisphere circulation and the Southern Oscillation. Papers and Proceedings of the Royal Society of Tasmania 122: 107-1. 12.

Anon. 2005: South Georgia and the South Sandwich Islands Overview of Financial Statements and Annual Statistics for the Year Ended 31st December 2005. Government of South Georgia and the South Sandwich Islands, Stanley: $10 \mathrm{pp}$.

Bergstrom, D.M. 1987: Evidence from fossils for uplift during the Holocene in Green Gorge, Macquarie Island. Colloque sur les ecosystèmes terrestres subantartiques. Comité National Français des Recherches Antartiques 58: 73-82. 
Bergstrom, D.M. \& Chown, S.L. 1999: Life at the front: history, ecology and change on southern ocean islands. Trends in Ecology and Evolution 14: 472-477.

Bergstrom, D.M., Turner, P.A.M., Scott, J.J., Copson G. \& Shaw J. 2006: Restricted plant species on subantarctic Macquarie and Heard islands. Polar Biology 29: 532-539.

Bester, M. N., Bloomer, J.P., Bartlett, P.A., Muller, D.D., van Rooyen, M. \& Buechner, H. 2000: Final eradication of feral cats from sub-Antarctic Marion Island, southern Indian Ocean. South African Journal of Wildlife Research 30: $53-57$.

Bonner, W.N. 1985: Impact of fur seals on the terrestrial environment at South Georgia. In Siegfried, W.R, Condy, P.R. \& Laws R.M. (eds): Antarctic Nutrient Cycles and Food Webs. Springer, Berlin: 641-646.

Bourzat, D. \& Monie, J.P. 1977: Evaluation des pâturages aux îles Kerguelen. I.N.P.S.A., Mémoire I.T.A., Dijon: 124 pp.

Boyd, I.L, Lunn, N.J., Rothery, P. \& Croxall, J.P. 1990: Age distribution of breeding female Antarctic fur seals in relation to changes in population growth rate. Canadian Journal of Zoology 68: 2209-2213.

Boyd I.L. 1993: Pup producrion and distribution of breeding Antarctic fur seals (Arctocephalus gazella) ar South Georgia. Antarctic Science 5: 17-24.

Chapuis, J.L., Boussès, P. \& Barnaud, G. 1994: Alien mammals, impact and management in the French subantarctic islands. Biological Conservation 67: 97-104

Chapuis, J.L., Frenot, Y. \& Lebouvier, M. 2004: Recovery of native plant communities after eradication of rabbits from the subantarctic Îles Kerguelen, and influence of climate change. Biological Conservation 117: 167-179.

Chown, S.L. \& Smith, V.R. 1993: Climate change and the shortterm impact of feral house mice at the sub-Antarctic Prince Edward Islands. Oecologia 96: 508-516.

Chown, S.L., Gremmen, N.J.M. \& Gaston, K.J. 1998: Ecological biogeography of Southern islands: species-area relationships, human impacts and conservation. American Naturalist 152: 562-575.

Chown, S.L., Hull, B. \& Gaston, K.J. 2005: Human impacts, energy availability and invasion across Southern Ocean Islands. Global Ecology and Biogeography 14: 521-528.

Convey, P., Barnes, D. \& Morton, A. 2002: Debris accumulation on oceanic island shores of the Scotia Arc, Antarctica. Polar Biology 25: 1432-2056.

Convey, P. 2006: Antarctic climate change and its influences on terrestrial ecosystems. In Bergstrom, D.M., Convey, P. \& Huiskes, A.D.H. (eds): Trends in Antarctic Terrestrial and Limnetic Ecosystems: Antarctica as a Global Indicator. Springer, Dordrecht: 253-272.

Convey, P., Frenot, Y., Gremmen, N. \& Bergstrom, D.M. 2006: Biological invasions. In Bergstrom, D.M., Convey, P. \& Huiskes, A.D.H. (eds): Trends in Antarctic Terrestrial and Limnetic Ecosystems: Antarctica as a Global Indicator. Springer, Dordrecht: 193-220.

Cooper, J., Crafford, J.E. \& Hecht, T. 1992: Introduction and extinction of brown trout (Salmo trutta L.) in an impoverished subantarctic stream. Antarctic Science 4: 9-14.

Copson, G. \& Whinam, J. 1998: Response of vegetation on subantarctic Macquarie Island to reduced rabbit grazing. Australian Journal of Botany 46: 15-24.

Copson, G. \& Whinam, J. 2001: Review of ecological restoration programme on subantarctic Macquarie Island: pest management progress and future directions. Ecological Management and Restoration 2: 129-138.

Coulon, F. \& Delille, D. 2006: Influence of substratum on the degradation processes in diesel polluted sub-Antarcric soils (Crozet Archipelago). Polar Biology 29: 806-12.

Croxall, J.P. 1998: Research and conservation: a future for albatrosses? In Robertson, G. \& Gales, R. (eds): Albatross Biology and Conservation. Surrey Beatty \& Sons, Chipping
Norton: 269-290.

Cumpston, J.S. 1968: Macquarie Island. ANARE Scientific Reports, Series A (1) Narrative. Antarctic Division, Department of External Affairs, Melbourne: 380 pp.

Deprez, P.P., Arens, M. \& Locher, H. 1994: Identification and Preliminary Assessment of Contaminated Sites in the Australian Antarctic Territory, 2. Macquarie Island. Unpublished report. Australian Antarctic Division, Hobart: $41 \mathrm{pp}$

Dixon, G. 2001: Management Strategies for Walking Tracks and Access Corridors in Macquarie Island Nature Reserve. Unpublished report. Parks and Wildlife Service, Tasmania: 55 pp.

Erskine, P.D., Bergstrom, D.M., Schmidt, S., Stewart, G.R., Tweedie, C.E. \& Shaw, J.D. 1998: Subantarctic Macquarie Island - a model ecosystem for studying animal-derived nitrogen sources using ${ }^{15} \mathrm{~N}$ natural abundance. Oecologia 117: 187-193.

Frenot, Y., Gloaguen, J.C. \& Tréhen, P. 1997: Climate change in Kerguelen Islands and colonization of recently deglaciated areas by Poa kerguelensis and $P$. annua. In Barraglia, B., Valencia, J. \& Walton, D.W.H. (eds): Antarctic Communities: Species, Structure and Survival. Cambridge University Press, Cambridge: 358--366.

Frenot, Y., Gloaguen, J.C., Cannavacciuolo, M. \& Bellido, A. 1998: Primary succession on glacier forelands in the subantarctic Kerguelen Islands. Journal of Vegetation Science 9: 75-84.

Frenot, Y., Chown S.L., Whinam, J., Selkirk, P.M., Convey, P., Skotnicki, M. \& Bergstrom, D.M. 2005: Biological invasions in the Antarctic: extent, impacts and implications. Biological Reviews 80: 45-72.

Frenot, Y., Convey, P., Lebouvier, M., Chown, S.L., Whinam, J., Selkirk, P.M., Skotnicki, M. \& Bergstrom, D.M. in press: Biological invasions: an environmental issue for Antarctica and the sub-Antarctic. Aliens in Antartica. Workshop Proceedings, Gateway Antarcrica, Christchurch, New Zealand.

Gales, R. 1998: Albatross populations: status and threats. In Robertson, G. \& Gales, R. (eds): Albatross Biology and Conservation. Surrey Beatty \& Sons, Chipping Norton: $20-45$.

Gordon, J.E. \& Timmis, R.J. 1992: Glacier fluctuations on South Georgia during the 1970 s and early 1980s. Antarctic Science 4: 215-226.

Gremmen, N.M.J., Chown, S.L. \& Marshall, D.J. 1998: Impact of the introduced grass Agrostis stolonifera on vegetation and soil fauna communities at Marion Island, subantarctic. Biological Conservation 85: 223-231.

Gremmen, N.J.M. \& Smith, V.R. 1999: New records of alien vascular plants from Marion and Prince Edward Islands, sub-Antarctic. Polar Biology 21: 401-409.

Headland, R. 1984: The Island of South Georgia. Cambridge University Press, Cambridge: 293 pp.

Hull, B.B. \& Bergstrom, D.M. 2006: Antarctic terrestrial and limnetic ecosystem conservation and management. In Bergstrom, D.M., Convey, P. \& Huiskes, A.D.H. (eds): Trends in Antarctic Terrestrial and Limnetic Ecosystems: Antarctica as a Global Indicator. Springet, Dordrecht: 317-340.

Hucke-Gaete R., Osman, L.P., Moreno, A. \& Torres, D. 2004: Examining natural population growth from near extinction: the case of the Antarctic fur seal at the South Shetlands, Antarctica. Polar Biology 27: 304-311.

Lancaster, M.L., Gemmell, N.J., Negro, S., Goldsworthy, S. \& Sunnucks P. 2006: Ménage à trois on Macquarie Island: hybridization among three species of fur seal (Arctocephalus spp.) following historical population extinction. Molecular Ecology 15: 3681-3692.

Leader-Williams, N. 1988: Reindeer on South Georgia: the Ecology of an Introduced Population. Cambridge University Press, Cambridge: 319 pp. 
Le Roux, P.C. \& McGeoch, M.A. 2007: Changes in climate extremes, variability and signature on sub-Antarctic Marion Island. Climate Change DO: 10.1007/S10584007-9259-7.

Lindsay, D.C. 1973: Effects of reindeer on plant communities in the Royal Bay area of South Georgia. British Antartic Survey Bulletin 35: 101-109.

McIntosh, E. \& Walton, D.W.H. 2000: Environmental Management Plan for South Georgia. Published by British Antarctic Survey on behalf of Government of South Georgia and the South Sandwich Islands: $104 \mathrm{pp}$.

Moen, J. \& MacAlister, H. 1994: Continued range expansion of introduced reindeer on South Georgia. Polar Biology 14: 459-462.

Page, B., Welling, A., Chambellant, M., Goldsworthy, S.D., Dorr, T. \& van Veen, R. 2003: Population status and breeding season chronology of Heard Island fur seals. Polar Biology 26: 219-224.

Parks and Wildlife Service. 2006: Macquarie Island Nature Reserve and World Heritage Area Management Plan. Parks and Wildlife Service, Department of Tourism Arts and the Environment, Hobart: $176 \mathrm{pp}$.

Pasceur, E. \& Walton, D.W. 2006: South Georgia: Plan for Progress, Managing the Environment 2006-2010. Arcessed 30 May 2007. http://www.sgisland.org/pages/ gov/PlanProgress.htm

Poland, J.S., Riddle, M.J. \& Zeeb, B.A. 2003: Contaminants in the Artic and the Antarctic: a comparison of sources, impacts and remediation options. Polar Record 39: 369-383.

Rayner, J.L, Snape, I., Walworth, J.L., Harvey, P.McA. \& Ferguson, S.H. 2007: Petroleum-hydrocarbon contamination and remediation by microbioventing at sub-Antarctic Macquarie Island. Cold Regions Science and Technology 48: 139-153.

Richardson, D.M., Pyšek, P., Rejmánek, M., Barbour, M.G., Panetta, F.D. \& West, C.J. 2000: Naturalization and invasion of alien plants: concepts and definitions. Diversity and Distributions 6: 93-107.

Ruddell, A. 2006: An inventory of present glaciers on Heard Island and their historical variation. In Green, K. \& Woehler, E.J. (eds): Heard Island: Southern Ocean Sentinel. Surrey Beatty \& Sons, Chipping Norton: 28-51.

Scott, J.J. 1990: Changes in vegetation of Heard Island 1947-1987. In Kerry, K.R. \& Hempel, G. (eds): Antarctic Ecosystems Ecological Change and Conservation. Springer-Verlag, Berlin: 61-76.

Scott, J.J. \& Bergstrom, D.M. 2006: Vegetation of Heard and McDonald Islands. In Green, K. \& Woehler, E.J. (eds): Heard Island: Southern Ocean Sentinel. Surrey Beatty \& Sons, Chipping Norton: 69-90.

Scott, J.J. \& Kirkpatrick J.B. 1994: Effects of human trampling on the sub-Antarctic vegetation of Macquarie Island. Polar Record 30: 207-220.

Scott, J.J. \& Kirkpatrick J.B. 2005: Changes in subantarctic Heard Island vegetation at sites occupied by Poa annua, 1987-2000. Arctic, Antarctic, and Alpine Research 37: $366-371$.

Selkirk, P.M. 1992: Climate change and the subantarctic. In Quilty, P.G. (ed.): Impact of Climate Change, AustraliaAntartica. Australian Government Printing Service, Canberra: $43-51$
Shaughnessy, P.D., Shaughnessy, G.L. \& Fletcher, L. 1988: Recovery of the fur seal population at Macquarie Island. Papers and Proceedings of the Royal Society of Tasmania 122: $177-187$

Slip, D.J. \& Burton, H.R. 1991: Accumulation of fishing debris, plastic litter, and other artefacts, on Heard and Macquarie Islands in the Southern Ocean. Environmental Conservation. 18: 249-254.

Smith, V.R. 2002: Climate change in the sub-Antarctic: an illustration from Marion 1sland. Climate Change 52 : 345-357.

Smith, V.R. \& Steenkamp, M. 1990: Climatic change and its ecological implications at a subantarctic island. Oecologia 85: 14-24.

Smith, V.R., Steenkamp, M. \& Gremmen, N.J.M. 2001: Terrestrial habitats on sub-Antarctic Marion Island: their vegetation, edaphic attributes, distribution and response to climate change. South African Journal of Botany 67: 641-654.

Springer, K. 2006: Macquarie Island - mammalian pests, past, present and future. Aliens 23: 14-17.

Sumner, P.D., Meiklejohn, K.I., Boelhouwers, J.C. \& Hedding, D.W. 2004: Climate change melts Marion Island's snow and ice. South African Journal of Science, 100: 395-398.

Taylor, R. 1979: How the Macquarie Island Parakeet became extinct. New Zealand Journal of Ecology 2: 42-45.

Tweedie, C.E. \& Bergstrom, D.M. 2000: A climate change scenario for surface air temperature at subantarctic Macquarie Island. In Davison, W., Howard-Williams, C. \& Broady, P.A. (eds): Antarctic Ecosystems: Models for Wider Ecological Understanding. New Zealand Natural Sciences, Christchurch: 272-281.

Weddell, J.L. 1825: A Voyage Towards the South Pole Performed in the Years 1822-24. Longman, Hunt, Rees, Orme, Brown and Green, London: $356 \mathrm{pp}$.

Whinam, J. \& Chilcott, N. 1999: Impacts of trampling on alpine environments in central Tasmania. Journal of Environmental Management 57: 205-220.

Whinam, J., Chilcott, N. \& Bergstrom, D.M. 2005: Subantarctic hitchhikers: expeditioners as vectors for the introduction of alien organisms. Biological Conservation 121: 207-219.

Whinam, J. \& Copson, G. 2006: Sphagnum moss: an indicator of climate change in the sub-Antarctic. Polar Record 42 : $43-49$.

Whinam J., Copson, G. \& Chapuis, J.L. 2006: Subantarctic terrestrial ecosystem conservation and management. In Bergstrom D.M., Convey, P. \& Huiskes A.H.L. (eds): Trends in Antarctic Terrestrial and Limnetic Ecosystems: Antarctica as a Global Indictor. Springer, Dordrecht: 297-316.

Whinam, J., Selkirk, P.M., Downing, A.J. \& Hull, B. 2004: Return of the megaherbs: plant colonisation of derelict ANARE station buildings on sub-Antarctic Heard Island. Polar Record 40: 235-243.

Wynen, L.P., Goldsworthy, S.D., Guinet, C., Bester, M.N., Boyd, I.L., Gjertz, I., Hofmeyr, G.J.G., White, R.W. \& Slade, R. 2000: Postsealing genetic variation and population structure of two species of fur seal (Arctocephalus gazella and A. tropicalis). Molecular Ecology 9: 229-314.

(accepted 24 September 2007) 